\title{
AN EXPLORATORY STUDY OF CIVIL SERVANTS SPATIAL THINKING, AWARENESS AND USE OF MAPS IN AFRICA-NIGERIA
}

\author{
R. A. Asiyanbola* \\ Department of Geography, Faculty of the Social Sciences, Osun State University, Osogbo, Nigeria - rasiyanbola@gmail.com
}

KEY WORDS: Space, Spatial thinking, Map, Civil servants, Nigeria

\begin{abstract}
:
The paper is an exploratory study of spatial thinking, awareness and use of maps among civil servants in Nigeria with a view towards enhancing capacity building in the development and use of global mapping and geospatial information technologies products and services. The data used in the paper was from administration of 152 questionnaires to civil servants in Ibadan, Oyo State, Nigeria between February and August, 2017. Descriptive statistics were used to analyse the data. The study shows among others that majority of the civil servants had situations in their daily lives or specialty that require spatial thinking; the three top situations in their daily lives or specialty that require spatial thinking were identification of places, wayfinding and walking; majority of them asked from people information about location, direction, distances and other needed information about places they do not know; majority of them were aware of maps; majority of them could read maps; majority of them had interest to learn more how to read maps and were willing to pay for the training.
\end{abstract}

\section{INTRODUCTION}

The literature reveals that earth based information has always been a critical type of information that humans - in fact, all animals - collect, organize, and use and place-based information is vital to survival on our planet (Dangermond, 2011). As observed in the literature, spatial thinking is thinking in, about and with space (Bednarz and Kemp, 2011). Wakabayashi and Ishikawa (2011) notes that spatial thinking is an interdisciplinary subject ranging from psychology and pedagogy to GIScience, and that no clear consensus yet exists concerning its definition. Accordingly, methods for assessing spatial thinking abilities have not yet sufficiently developed (Wakabayashi and Ishikawa, 2011; NRC, 2006).

Observation in the literature shows that spatial thinking is at the heart of many great discoveries in science, that it underpins many of the activities of the modern workforce, and that it pervades the everyday activities of modern life (Bednarz and Kemp, 2011; NRC, 2006). Bednarz and Kemp (2011) notes that to geographers and other scholars engaged in "the spatial turn," being able to think in, with, and through space, that is, to be spatially proficient, is increasingly valuable and generative (Cosgrove, 2004; Fujita et al, 2001; Goodchild and Janelle, 2010). In the literature spatial thinking/literacy is featured through 'the spatial 'whereness' - embodied in specific questions such as, where is it? Why is it there?" (Bednarz and Kemp, 2011; Geography Education Standards Project, 1994). Everyday people ask these questions in order to meet daily needs. Spatial thinking is seen as a constructive amalgam of three elements which include: concepts of space; tools of representation; and, processes of reasoning (Bednarz and Kemp, 2011; Wakabayashi and Ishikawa, 2011; Bednarz and Lee, 2011; NRC, 2006). Thus to think spatially, according to the literature (Bednarz and Kemp, 2011)), one must develop a knowledge of spatial concepts such as direction, distance, and spatial association; attain skills in constructing and interpreting graphic representations such as diagrams, maps, and graphs; and acquire and practice the cognitive strategies (or habits of mind) that facilitate problem-solving and decision-making in spatial contexts. The literature show that geographic information science which is the study of the fundamental issues of geographic information is often motivated by the need to improve geographic information technologies (Goodchild, 2011). According to Goodchild (2011), recent efforts have led to a comprehensive understanding of the concepts of spatial thinking, and how these concepts might form the basis for a much-improved functionality and user interface.

In Nigeria, study that have examined how is spatial thinking, awareness and use of maps particularly in the current era of geospatial information technologies and global mapping is rare. Thus, the paper is an exploratory study of spatial thinking, awareness and use of maps among civil servants in Nigeria with a view towards enhancing capacity building in the development and use of global mapping and geospatial information technologies products and services.

The paper is divided into five sections. The first section is this introduction, followed by the research questions in section two, method of the study in section three, findings of the research in section four and conclusion in section five..

\section{RESEARCH QUESTIONS}

The research questions which were addressed in the paper include: Do civil servants have situations in their daily lives or specialty that require spatial thinking? What are the situations in their daily lives or specialty that require spatial thinking? How often do they encounter situations in their daily lives or specialty that require spatial thinking? How do they get information about location, direction, distances and other

\footnotetext{
* Corresponding author
} 
needed information about places they do not know? Are they aware of maps? Do they know how to read maps? Were they ever taught how to read maps? Do they know what maps are used for? Have they ever use maps? Are they aware of existence of maps on the internet? Have they ever browse the maps on the internet? What did they browse the maps on the internet for? How often do they browse maps on the internet? Which online maps are they aware of? Which online maps have they browse and use? Are they aware that some cell phone can browse maps on the internet? Do they use cell phone to browse maps on the internet? Do they have interest to learn how to read maps? Do they know where they can be trained on how to read maps? Are they willing to pay for the training? What are the challenges they faced?

\section{METHOD OF THE STUDY}

The data used in the study was obtained from primary and secondary sources. The primary data was collected through administration of questionnaires. Information collected through the questionnaires include information about civil servants spatial thinking, awareness and use of maps and challenges they faced. A total of one hundred and fifty-two (152) questionnaires were administered to civil servants in five Local Governments in Ibadan metropolitan area and at the Oyo State Government Secretariat in Ibadan between February and August, 2017. Twenty-five (25) questionnaires were administered at each of the five Local Government in Ibadan metropolitan area and twenty-seven (27) questionnaires were administered at the Oyo State Secretariat. The five Local Governments in Ibadan metropolitan area were: Ibadan North Local Government, Ibadan North East Local Government, Ibadan North West Local Government, Ibadan South East Local Government, and Ibadan South West Local Government. Descriptive statistics were used to analyse the data.

\section{FINDINGS OF THE RESEARCH}

\subsection{Civil servants' responses to questions relating to their spatial thinking:}

Table 1 shows civil servants' responses to questions relating to their spatial thinking. The table shows that majority (93.0) of the civil servants had situations in their daily lives or specialty that require spatial thinking. Some $(30.0 \%)$ of them said that they often encountered situations in their daily lives or specialty that require spatial thinking. The three top situations in their daily lives or specialty that require spatial thinking were identification of places (73.0\%), wayfinding (64.0\%) and walking $(58.0 \%)$. The three top methods of getting information about location, direction, distances, and needed information about places they do not know were by asking from people, browsing the internet and from map/search from books. However, the result shows that majority of them asked from people information about location, direction, distances and other needed information about places they do not know.

\begin{tabular}{|l|l|l|l|}
\hline S/N & Questions & Response & $\begin{array}{l}\text { Percentage } \\
\%(\mathrm{n}=152)\end{array}$ \\
\hline 1 & $\begin{array}{l}\text { Do you have } \\
\text { situations in your } \\
\text { daily lives or }\end{array}$ & Yes & 93.0 \\
\hline
\end{tabular}

\begin{tabular}{|c|c|c|c|}
\hline & $\begin{array}{l}\text { specialty that } \\
\text { require spatial } \\
\text { thinking, that is, } \\
\text { thinking about } \\
\text { location, direction, } \\
\text { distance, etc. ? }\end{array}$ & & \\
\hline \multirow[t]{5}{*}{2} & \multirow{5}{*}{$\begin{array}{l}\text { How often do you } \\
\text { encounter } \\
\text { situations in your } \\
\text { daily lives or } \\
\text { specialty that } \\
\text { require spatial } \\
\text { thinking, that is, } \\
\text { thinking about } \\
\text { location, direction, } \\
\text { distance, etc.? }\end{array}$} & Often & 30.0 \\
\hline & & Sometimes & 13.0 \\
\hline & & Occasionally & 34.0 \\
\hline & & Not often & 8.0 \\
\hline & & Not at all & 4.0 \\
\hline \multirow[t]{8}{*}{3} & \multirow{8}{*}{$\begin{array}{l}\text { Mention the } \\
\text { situations in your } \\
\text { daily lives or } \\
\text { specialty that } \\
\text { require spatial } \\
\text { thinking, that is, } \\
\text { thinking about } \\
\text { location, direction, } \\
\text { distance, etc.? }\end{array}$} & Wayfinding & 64.0 \\
\hline & & Route planning & 38.0 \\
\hline & & Walking & 58.0 \\
\hline & & Driving & 34.0 \\
\hline & & $\begin{array}{l}\text { Identification of } \\
\text { places }\end{array}$ & 73.0 \\
\hline & & $\begin{array}{l}\text { Description of } \\
\text { places }\end{array}$ & 38.0 \\
\hline & & $\begin{array}{l}\text { Map use and } \\
\text { making }\end{array}$ & 16.0 \\
\hline & & $\begin{array}{l}\begin{array}{l}\text { Others } \\
\text { specify) }\end{array} \quad \text { (please } \\
\end{array}$ & 0.0 \\
\hline \multirow[t]{5}{*}{4} & \multirow{5}{*}{$\begin{array}{l}\text { How do you get } \\
\text { information about } \\
\text { location to places } \\
\text { you do not know? }\end{array}$} & Ask from people & 68.0 \\
\hline & & $\begin{array}{l}\text { Browsing the } \\
\text { internet }\end{array}$ & 50.0 \\
\hline & & $\begin{array}{l}\text { Map/Searching } \\
\text { from Books }\end{array}$ & 11.0 \\
\hline & & $\begin{array}{lr}\text { Use } & \text { google } \\
\text { search/google map }\end{array}$ & 8.0 \\
\hline & & Road Signboard & 0.0 \\
\hline \multirow[t]{5}{*}{5} & \multirow{5}{*}{$\begin{array}{l}\text { How do you get } \\
\text { information about } \\
\text { direction to places } \\
\text { you do not know? }\end{array}$} & Ask from people & 65.0 \\
\hline & & $\begin{array}{l}\text { Browsing the } \\
\text { internet }\end{array}$ & 50.0 \\
\hline & & $\begin{array}{l}\text { Map/Searching } \\
\text { from Books }\end{array}$ & 11.0 \\
\hline & & $\begin{array}{lr}\text { Use } & \text { google } \\
\text { search/google map }\end{array}$ & 9.0 \\
\hline & & Road Signboard & 1.0 \\
\hline \multirow[t]{5}{*}{6} & \multirow{5}{*}{$\begin{array}{l}\text { How do you get } \\
\text { information about } \\
\text { distances to places } \\
\text { you do not know? }\end{array}$} & Ask from people & 63.0 \\
\hline & & $\begin{array}{l}\text { Browsing the } \\
\text { internet }\end{array}$ & 52.0 \\
\hline & & $\begin{array}{l}\text { Map/Searching } \\
\text { from Books }\end{array}$ & 11.0 \\
\hline & & $\begin{array}{lr}\text { Use } & \text { google } \\
\text { search/google map }\end{array}$ & 7.0 \\
\hline & & Road Signboard & 0.0 \\
\hline \multirow[t]{5}{*}{7} & \multirow{5}{*}{$\begin{array}{l}\text { How do you get } \\
\text { your } \\
\text { information about } \\
\text { places? }\end{array}$} & Ask from people & 66.0 \\
\hline & & $\begin{array}{l}\text { Browsing the } \\
\text { internet }\end{array}$ & 55.0 \\
\hline & & $\begin{array}{l}\text { Map/Searching } \\
\text { from Books }\end{array}$ & 13.0 \\
\hline & & $\begin{array}{lr}\text { Use } & \text { google } \\
\text { search/google map }\end{array}$ & 9.0 \\
\hline & & Road Signboard & 0.0 \\
\hline
\end{tabular}

Table 1: Civil servants' responses to questions relating to their spatial thinking (Source: Field survey, 2017) 


\subsection{Civil servants' responses to questions relating to their awareness and use of Maps:}

Table 2 shows the civil servants' responses to questions relating to their awareness and use of maps. The table shows that majority of the civil servants were aware of maps $(95.0 \%)$ and know what maps were used for $(84.0 \%)$. Majority of them said that they know how to read maps $(80.0 \%)$ and had used maps $(82.0 \%)$. Majority $(76.0 \%)$ of them said that they were taught how to read maps when they were in school. Few of them said that they used maps daily $(16.0 \%)$, and some of them said that they used maps occasionally $(48.0 \%)$. The table also shows that majority of the civil servants were aware of existence of maps on the internet $(74.0 \%)$ and had browsed maps on the internet $(69.0 \%)$. Few of them said that they browsed maps on the internet daily $(14.0 \%)$, and some of them said that they browsed maps on the internet occasionally $(44.0 \%)$. The three top reasons for browsing maps on the internets were to get location, direction, and distances to places. The three top online maps they were aware of are Google Maps, Google Earth, and Bing Maps. The three top online maps they had browsed on the internet and used were Google Maps, Bing maps and Google Earth.

The table further show that majority of the civil servants were aware that some cell phone can browse maps on the internet $(86.0 \%)$ and most of them had used cell phone to browse maps on the internet $(65.0 \%)$. Majority of them said that they had interest to learn more how to read maps $(80.0 \%)$. Some of them said that they do not know where they can be trained more on how to read maps $(40.0 \%)$. When asked whether they were willing to pay for the training, most of them said yes $(68.0 \%)$ that they were willing to pay for the training, while some of them said no $(30.0 \%)$ that they were not willing to pay for the training.

Among the challenges they said they faced were: electricity (power supply) problem and low battery capacity of the cell phone and of the personal computer/Laptop, lack of finance to pay for the training and to buy cell phone and computer that can browse, lack of understand of map terminology and how to read maps.

\begin{tabular}{|c|c|c|c|}
\hline $\mathrm{S} / \mathrm{N}$ & Questions & Response & $\begin{array}{l}\text { Percentage } \\
\%(\mathrm{n}=152)\end{array}$ \\
\hline \multirow[t]{2}{*}{1} & \multirow{2}{*}{$\begin{array}{l}\text { Are you aware of } \\
\text { Maps? }\end{array}$} & Yes & 95.0 \\
\hline & & No & 5.0 \\
\hline \multirow[t]{2}{*}{2} & \multirow{2}{*}{$\begin{array}{l}\text { Do you know what } \\
\text { Maps are used for? }\end{array}$} & Yes & 84.0 \\
\hline & & No & 15.0 \\
\hline \multirow[t]{2}{*}{3} & \multirow{2}{*}{$\begin{array}{l}\text { Do you know how to } \\
\text { read Maps? }\end{array}$} & Yes & 80.0 \\
\hline & & No & 18.0 \\
\hline \multirow[t]{2}{*}{4} & \multirow{2}{*}{$\begin{array}{l}\text { Have you ever use } \\
\text { Maps? }\end{array}$} & Yes & 82.0 \\
\hline & & No & 17.0 \\
\hline \multirow[t]{2}{*}{5} & \multirow{2}{*}{$\begin{array}{l}\text { When you were in } \\
\text { school were you } \\
\text { taught how to read } \\
\text { maps? }\end{array}$} & Yes & 76.0 \\
\hline & & No & 14.0 \\
\hline \multirow[t]{6}{*}{6} & \multirow{6}{*}{$\begin{array}{l}\text { How often do you } \\
\text { use Maps? }\end{array}$} & Daily & 16.0 \\
\hline & & Once a week & 9.0 \\
\hline & & Once a month & 4.0 \\
\hline & & Occasionally & 48.0 \\
\hline & & $\begin{array}{l}\text { Rarely (Almost } \\
\text { never) }\end{array}$ & 6.0 \\
\hline & & Not at all & 12.0 \\
\hline
\end{tabular}

\begin{tabular}{|c|c|c|c|}
\hline \multirow[t]{2}{*}{7} & \multirow{2}{*}{$\begin{array}{l}\text { Are you aware of } \\
\text { existence of Maps on } \\
\text { the internet? }\end{array}$} & Yes & 74.0 \\
\hline & & No & 20.0 \\
\hline \multirow[t]{2}{*}{8} & \multirow{2}{*}{$\begin{array}{l}\text { Have you ever } \\
\text { browse the Maps on } \\
\text { the internet? }\end{array}$} & Yes & 69.0 \\
\hline & & No & 29.0 \\
\hline \multirow[t]{6}{*}{9} & \multirow{6}{*}{$\begin{array}{l}\text { How often do you } \\
\text { browse Maps on the } \\
\text { internet }\end{array}$} & Daily & 14.0 \\
\hline & & Once a week & 8.0 \\
\hline & & Once a month & 6.0 \\
\hline & & Occasionally & 44.0 \\
\hline & & $\begin{array}{l}\text { Rarely (Almost } \\
\text { never) }\end{array}$ & 6.0 \\
\hline & & Not at all & 16.0 \\
\hline \multirow[t]{4}{*}{10} & \multirow{4}{*}{$\begin{array}{l}\text { What did you browse } \\
\text { the Maps on the } \\
\text { internet for? }\end{array}$} & $\begin{array}{l}\text { To get location } \\
\text { of places }\end{array}$ & 67.0 \\
\hline & & $\begin{array}{lr}\text { To } & \text { get } \\
\text { direction } & \text { to } \\
\text { places } & \end{array}$ & 45.0 \\
\hline & & $\begin{array}{lr}\text { To } & \text { get } \\
\text { distances } & \text { to } \\
\text { places } & \\
\end{array}$ & 40.0 \\
\hline & & Others & 1.0 \\
\hline \multirow[t]{5}{*}{11} & \multirow{5}{*}{$\begin{array}{l}\text { Which online Maps } \\
\text { are you aware of? }\end{array}$} & Google Earth & 36.0 \\
\hline & & Google Maps & 65.0 \\
\hline & & Bing Maps & 32.0 \\
\hline & & None & 15.0 \\
\hline & & Others & 0.0 \\
\hline \multirow[t]{5}{*}{12} & \multirow{5}{*}{$\begin{array}{l}\text { Which online Map } \\
\text { have you browse and } \\
\text { use? }\end{array}$} & Google Earth & 22.0 \\
\hline & & Google Maps & 63.0 \\
\hline & & Bing Maps & 27.0 \\
\hline & & None & 16.0 \\
\hline & & Others & 0.0 \\
\hline \multirow[t]{2}{*}{13} & \multirow{2}{*}{$\begin{array}{l}\text { Are you aware that } \\
\text { some cell phone can } \\
\text { browse Maps on the } \\
\text { internet? }\end{array}$} & Yes & 86.0 \\
\hline & & No & 12.0 \\
\hline \multirow[t]{2}{*}{14} & \multirow{2}{*}{$\begin{array}{l}\text { Do you use cell } \\
\text { phone to browse } \\
\text { Maps on the internet? }\end{array}$} & Yes & 65.0 \\
\hline & & No & 32.0 \\
\hline \multirow[t]{2}{*}{15} & \multirow{2}{*}{$\begin{array}{l}\text { Do you have interest } \\
\text { to learn (more) how } \\
\text { to read Maps? }\end{array}$} & Yes & 80.0 \\
\hline & & No & 16.0 \\
\hline \multirow[t]{2}{*}{16} & \multirow{2}{*}{$\begin{array}{l}\text { Do you know where } \\
\text { you can be trained on } \\
\text { how to read Maps? }\end{array}$} & Yes & 46.0 \\
\hline & & No & 40.0 \\
\hline \multirow[t]{2}{*}{17} & \multirow{2}{*}{$\begin{array}{l}\text { Are you willing to } \\
\text { pay for the training? }\end{array}$} & Yes & 68.0 \\
\hline & & No & 30.0 \\
\hline
\end{tabular}

Table 2: Civil servants' responses to questions relating to their awareness and use of Maps (Source: Field survey, 2017)

\section{CONCLUSION}

This paper has carried out an exploratory study of civil servants awareness and use of maps in Ibadan, Oyo State, Nigeria. The findings include: majority of the civil servants had situations in their daily lives or specialty that require spatial thinking; the three top situations in their daily lives or specialty that require spatial thinking were identification of places, wayfinding and walking; majority of them asked from people information about location, direction, distances and other needed information about places they do not know; majority of them were aware of maps; majority of them could read maps; majority of them had 
interest to learn more how to read maps and were willing to pay for the training; some of them said that they do not know where they can be trained more on how to read maps. Among the challenges they said they faced were: electricity (power supply) problem and low battery capacity of the cell phone and of the personal computer/Laptop, lack of finance to pay for the training and to buy cell phone and computer that can browse, lack of understand of map terminology and how to read maps. The findings of this study shows that there is need for geospatial information technology firms to create more awareness of their existence/products and services they offer as well as have branches at accessible locations and provide training at affordable price. The government need to provide enabling environment and financial support for the civil servant for training and re-training programmes in geospatial information technologies. There is also the need for improvement in electricity supply/internet facilities and more places needs to be put on the map.

\section{ACKNOWLEDGEMENTS}

The author wishes to appreciate the effort of Mr. Akinola Ishaq Enitan a postgraduate student in the Department of Urban and Regional Planning, University of Ibadan, Ibadan, Nigeria, who assisted in the field survey.

\section{REFERENCES}

Bednarz R.S., Lee J., 2011. "The components of spatial thinking: empirical evidence". Procedia Social and Behavioral Sciences 21:103-107

Bednarz S.W., Kemp K., 2011. Understanding and nurturing spatial literacy. Procedia Social and Behavioral Sciences, 21: $18-23$

Cosgrove D., 2004. Landscape and landschaft. German Historical Institute Bulletin 35:57-71

Dangermond J., 2011, 'GIS: A language for understanding'. A keynote presentation at the 2011 ESRI International User Conference in San Diego, California, July 11-15, 2011 ARCNEWS Esri Fall Vol. 33, No. 3 p. 1, 7.

Fujita M., Krugman P., Venables A.J., 2001. The economy: Cities, regions, and international trade. Boston: MIT Press

Geography Education Standards Project, 1994. Geography for life: national geography standards. Committeefor Science and Exploration. Washington DC

Golledge R.G., Marsh M., Battersby S.E., 2008. Matching geospatial concepts with geographic education needs. Geographical Research 46(1):85-98

Goodchild F. M., 2011. "Spatial thinking and GIS User Interface”, Procedia Social and Behavioral Sciences 21:3-9

Goodchild, M.F., Janelle, D.G., 2010. Towards critical spatial thinking in the social sciences and humanities. GeoJournal $75: 3-13$
NRC (National Research Council), 2006. Learning to think spatially. Washington DC: National Academies Press

Wakabayashi Y., Ishikawa T., 2011. "Spatial thinking in geographic information science: a review of past studies and prospects for the future". Procedia Social and Behavioral Sciences 21:304-313 